\title{
Utility of some floral characters in the assessment of genetic diversity in sesame (Sesamum indicum L.)
}

\author{
Musibau. A. AZEEZ ${ }^{1 *}$, Modupe. B. OLOWOOKERE ${ }^{1}$, David. A. ANIMASAUN ${ }^{2}$, Bashir. O. BELLO ${ }^{3}$
}

Received June 08, 2016; accepted November 26, 2016.

Delo je prispelo 08. junija 2016, sprejeto 26. novembra 2016.

\begin{abstract}
Sesame collections were evaluated for quantitative floral characters and data obtained were subjected to various statistical analyses. Result showed narrow diversity in most of the quantitative floral characters with moderate variability in length of flower (2.03-3.27 cm), length of style (1.10$1.40 \mathrm{~cm})$, length of capsule $(2.33-2.98 \mathrm{~cm})$ and number of seeds per capsule $(38.67-57.67)$. Correlation study revealed significantly $(p<0.01)$ positive correlations for length of ovary versus length of flower $(r=0.70)$ and length of capsule versus length of style $(\mathrm{r}=0.77)$. The first two principal components accounted for $61.59 \%$ of which the first component had $34.13 \%$ and the second was $27.46 \%$. Dendrogram divided the seventeen accessions/landraces into two major groups (A and B). Group A had only one cluster with five members whilegroup B had three clusters (Cluster II, III and IV) with seven, three and two members respectively. Each accession within a cluster could be employed as baseline parent in crossbreeding for improvement of yield in Nigerian sesame.
\end{abstract}

Key words: Sesamum indicum; accessions; multivariate analysis; floral characters; principal components; clusters; genetic diversity; dendrogram

\section{IZVLEČEK}

\section{UPORABNOST NEKATERIH LASTNOSTI CVETOV PRI VREDNOTENJU GENETSKE RAZNOLIKOSTI SEZAMA (Sesamum indicum L.)}

Zbirke sezamovih genotipov so bile ovrednotene po nekaterih kvantitativnih lastnostih cveta in nato podvržene različnim statističnim analizam. Rezultati so pokazali majhno variabilnost pri večini vključenih lastnosti, z zmerno raznolikostjo $\mathrm{v}$ dolžini cveta $(2.03-3.27 \mathrm{~cm})$, dolžini vratu pestiča $(1.10-1.40 \mathrm{~cm})$, dolžini glavice $(2.33-2.98 \mathrm{~cm})$ in $\mathrm{v}$ številu semen na glavico $(38.67$ - 57.67). Korelacijske raziskave so pokazale značilno $(p<0.01)$ pozitivno korelacijo med dolžino plodnice in dolžino cveta $(\mathrm{r}=0.70)$ ter dolžino glavice in dolžino vratu pestiča $(\mathrm{r}=0.77)$. Prvi dve glavni komponenti variabilnosti sta znašali $61.59 \%$, kjer je prva komponenta obsegala $34.13 \%$ in druga $27.46 \%$. Dendrogram je razdelil 17 akcesij v dve glavni skupini (A in B). Skupina A je imela samo en klaster s petimi akcesijami, medtem, ko je skupina B obsegala tri klastre (klaster II, III in IV) s sedmimi, tremi in dvema akcesijama. Vsako od akcesij $\mathrm{v}$ navedenih klastrih bi lahko uporabili kot izhodiščno starševsko linijo pri hibridizaciji, s ciljem izboljšanja produktivnosti sezama $\mathrm{V}$ Nigeriji.

Ključne besede: Sesamum indicum; akcesije; multivariatna analiza; cvetne lastnosti; PCA; klastri; genetska raznolikost; dendrogram

\section{INTRODUCTION}

Sesame (Sesamum indicum L.) is a flowering plant belonging to the genus Sesamum with numerous wild relatives occurring in Africa. It is believed to have originated either around the Fertile Crescent or the Indian subcontinent or Iran-Afghanistan region (Ashri, 1989; Mohamed and Awatif, 1998;
Pathak et al., 2014). The prediction of Africa as probably the primary centre of origin of cultivated sesame because of the preponderance of the wild species of the plant in the region was defeated by lack of genetic variability. However, genetic variability for cultivated sesame has been found to

\footnotetext{
1 Department of Pure and Applied Biology, Ladoke Akintola University of Technology, PMB 4000, Ogbomoso, Oyo State, Nigeria; *Corresponding author : maazeez@lautech.edu.ng

2 Department of Plant Biology, University of Ilorin, Ilorin, Kwara State, Nigeria. Email: animasaun.ad@unilorin.edu.ng

3 Department of Biological Sciences, Fountain University, Osogbo, Osun State, Nigeria. Email: obbello2002@yahoo.com
} 
be abundant in India subcontinent. Moreover, sesame seed and oil are well referenced in several Hindus scriptures as far back as $1500 \mathrm{BC}$ and have since become important components of Hindus rituals and offerings (Bhat et al. 1999). Scientific evidences of successful crosses and production of fertile hybrid between $S$. malabaricum Burm. ,(a wild form), only reported from Malabar in the west coast of India and S. orientale L. (Hiremath and Patil, 1999) suggested the origin of cultivated sesame from wild populations native to India. Close phylogenetic relationship between the two taxa based on RAPD markers (Bhat et al., 1999; Nanthakumar et al., 2000), chemical data and existence of enormous genetic variability further supported the view that sesame was domesticated in the Indian subcontinent (Bedigian, 2003).

Sesame is cultivated for its edible seeds which are produced in capsules. Sesame seeds come in variety of colors from cream to white to charcoal black (Bedigian, 2006). In general, the paler varieties of sesame seem to be more valued in the West and Middle East, while the black varieties are prized in the Far East. Sesame seeds and oil are put to great variety of uses. Sesame seeds are primarily a source of oil for cooking in India subcontinent and African countries (Bhat et al., 1999). The seeds, hulled or unhulled, roasted or raw are widely used in European and North American bakery industry as a garnish on bread products. About one third of the sesame crops imported by the United States from Mexico are purchased by McDonalds for their sesame seeds buns (Anon, 2002). In Nigeria, the crop, often referred to as beniseed is widely used and very popular in parts of the central, north western and north eastern zones where it is usually grown (Falusi and Salako, 2001). The most popular species in cultivation is Sesamum indicum, which has hundreds of varieties and strains with considerable variation in size, seed, color and composition. Some wild varieties are also cultivated to some extent for their leaves used as vegetable and medicinal decoctions (Uzo et al., 1985).

The inflorescence type in sesame is spike with flowers that are zygomorphic, and located in leaf axil (Ruhi et al., 2015). Each of the flowers has five petals with white and pink color, and the lower petal is longer with lip folded over the top, keeping it closed to around sunrise; when it opens to form a running strip for bees (Langham, 2007). The stamens are didynamous and the ovary is superior (as in hypogynous flower), bi/tetracarpellate and each carpel has two locules. Its fruit is capsule consisting of oleaginous seeds, of which most of the capsules are dehiscent (Kumar and Hiremath, 2008). Sesame is known to possess greater genetic variability than most of the self-pollinated crops. Kobayashi (1981) considered morphological data such as branching habits, number of flower per axil, capsule type and seed coat color, and employed them to study genetic diversity in which some sesame genotypes were closely grouped in sub clusters. Similar results indicating diversity among varieties of different clusters using morphological characters have been reported by Furini and Wunder (2004). Zhigila et al. (2015) used morphometric characters to delimit some accessions of $S$. indicum collected from Nigeria.

The study of floral development is important in helping to understand phylogenetic relationships among plants (Buzgo et al., 2004). Suarez-Cervera et al. (1992) studied the pollen morphology in the Pedaliaceae family, while Ruhi et al. (2015) studied anatomical structure of vegetative organs, floral meristem and pollen development in sesame. Azeez and Morakinyo (2011a, 2011b) inferred genetic diversity among the cultivated and wild accessions of sesame using seed physical dimensions, seed oil and fatty acid profile. In another study, Azeez, et al. (2013) established genetic diversity in sesame and its crosses using crude seed protein while Alege (2015) also used this same technique to investigate genetic diversity in some Nigerian sesame. Several studies have reported the use of isozymes (Isshiki and Umezaki, 1997; Nyongesa et al., 2014) and DNA markers (Akbar et al., 2011; Wei et al., 2011; Adeoti et al., 2011) in the analyses of genetic diversity in sesame. However, there is dearth of knowledge on the usefulness of quantitative reproductive characters in the assessment of genetic diversity in sesame. As a result, this study was designed and aimed at assessing the variability among seventeen accessions of sesame using floral characters with a view to identify promising accessions for future breeding programs. 


\section{MATERIALS AND METHODS}

Seventeen accessions/landraces of sesame seeds used in this study were collected from National Cereal Research Institute (NCRI), Badegi Niger State and across other five States (i.e. Oyo, Kwara, Kogi, Jigawa and Katsina) in Nigeria. The seeds were sown in Nursery bags on the research field of the Department of Pure and Applied Biology, LAUTECH, Ogbomoso in January 2009. The seedlings emerged 3 to 4 days after sowing and were constantly watered for two weeks before the seedlings from each Nursery bag were transplanted 2 plant stands per bag. Each accession was replicated in 18 bags out of which nine bags were later selected and were divided into three plots with arrangement following complete randomization pattern. Inter-row and within row spacing of $0.5 \mathrm{~m}$ was maintained throughout. Identities of the accessions used and their seed color are given in Table 1.

A total of 10 floral characters were recorded in this study. They include, length of flower, length of ovary, length of two upper anthers, length of two lower anthers, length of two upper filaments, length of two lower filaments, length of style, length of capsule, breadth of capsule, and number of seeds per capsule. Means and standard error of means were used to determine central tendency and dispersion for the reproductive characters recorded. Estimate of analyses of genetic diversity was executed using SPSS for window 7.0, version 16 (Norusis, Munich, Germany). Degree of association among the various floral characters was assessed using Pearson's correlation. Principal component analyses were performed to evaluate the contribution of each character to genetic diversity and the total variation was calculated as the sum of extracted eigenvalues. Grouping of accessions/landraces into similar categories was performed by estimates for Euclidean dissimilarity coefficients for floral data while hierarchical cluster analysis was carried out and dendrogram of relationship based on Ward's method was constructed using SPSS version 16 (Azeez et al., 2013).

\section{RESULTS}

Most of the floral characters measured exhibited narrow variability except for length of flower, length of style, length of capsule and number of seeds per capsule. Most accessions/landraces used in the study were white seeded $(64.71 \%)$, while others with brown and black seeds were equally represented. Majority of the accessions/landraces evaluated produced white flowers at flowering stage ( $82.35 \%$ of total collections), while others which were black seeded produced purple colored flowers. Mean values calculated for all the floral characters' studied revealed moderate variability in length of flower $(2.03-3.27 \mathrm{~cm})$, length of style $(1.10-1.40 \mathrm{~cm})$, length of capsule $(2.33-2.98$ $\mathrm{cm}$ ) and number of seeds per capsule (38.67 57.67) as shown in Table 2. Eight of the correlation coefficients were positive and significant (Table 3), out of which only 3 were highly significantly correlated $(p<0.01)$. The highest positive correlation was between length of the two lower filaments and length of the two upper filaments $(r=0.78)$, followed by length of capsule versus length of style $(r=0.77)$ and length of ovary versus length of flower $(r=0.70)$. Length of ovary was negatively correlated with length of the two lower anthers $(\mathrm{r}=-0.55)$ and length of the two upper anthers $(\mathrm{r}=-0.50)$ (Table 3$)$.

The principal components analyses (Table 4) revealed that the first two principal components accounted for $61.59 \%$ of the total variability among the accessions/landraces. Most variation was explained by the first component $(34.13 \%)$, followed by the second $(27.46 \%)$. The first component had high positive loadings from length of ovary (0.75), length of style (0.74), length of flower (0.71) and length of capsule (0.66) while it had high negative loading from length of two lower anthers (-0.69). The second component also had high positive loadings from length of the two upper anthers (0.75), length of the two upper filaments (0.70), length of the two lower filaments (0.66) while it recorded high negative loadings for breadth of capsule $(-0.63)$ and number of seeds per capsule (-0.61). However, none of the characters was redundant. 
Musibau. A. AZEEZ et al.

Table 1: List of studied accessions/landraces of sesame and their seed color

\begin{tabular}{llll}
\hline Accession No. & Code & Source/Origin & Seed Color \\
\hline 1. & 69B-882 & NCRI, Badeji, Niger State & Brown \\
2. & AYK & Kabah, Kogi State & Black \\
3. & EVA & NCRI Badeji, Niger State/FAO Italy & Dirty white \\
4. & 65-8B & NCRI, Badeji, Niger State & Brown \\
5. & C-K2-1 & NCRI, Badeji, Niger State & Light brown \\
6. & Bode Saadu, Kwara State & Black \\
7. & PACH & NCRI, Badeji, Niger State /FAO Italy & Dirty white \\
8. & GUMEL Local & Jigawa State & Dirty white \\
9. & DANEKA I & Katsina State & Dirty white \\
10. & C-K2-2 & NCRI, Badeji, Niger State & White \\
11. & DANKASCO Local & Jigawa State Nigeria & White \\
12. & E-8 & NCRI, Badeji, Niger State & White \\
13. & S530 & NCRI, Badeji, Niger State & Dirty white \\
14. & DANKASCO I & Jigawa State & Creamy white \\
15. & BATSARI Local & Katsina State & White \\
16. & ZABURAN Local & Jigawa State & White \\
17. & ALO & Ogbomoso, Oyo State & Black \\
\hline
\end{tabular}

Table 2: Statistical parameters for sesame floral characters

\begin{tabular}{lccc}
\hline \multicolumn{1}{c}{ Traits } & Range & Mean & S.E. \\
\hline Length of flower & $2.03-3.27$ & 2.84 & 0.07 \\
Length of ovary & $0.30-0.45$ & 0.37 & 0.01 \\
Length of two upper anthers & $0.30-0.40$ & 0.35 & 0.01 \\
Length of two lower anthers & $0.25-0.40$ & 0.33 & 0.01 \\
Length of two upper filaments & $1.00-1.17$ & 1.02 & 0.01 \\
Length of two lower filaments & $0.90-0.99$ & 0.92 & 0.01 \\
Length of style & $1.10-1.40$ & 1.20 & 0.02 \\
Length of capsule & $2.33-2.98$ & 2.58 & 0.05 \\
Breadth of capsule & $0.80-0.88$ & 0.83 & 0.01 \\
Number of seeds per capsule & $38.67-57.67$ & 50.69 & 1.40 \\
\hline
\end{tabular}

Table 3: Correlation among analyzed sesame floral characters

\begin{tabular}{|c|c|c|c|c|c|c|c|c|c|c|}
\hline Character & $\mathrm{LOF}$ & LOV & LUA & LLA & LUF & LLF & LOS & LOC & BOC & NSC \\
\hline LOF & 1.00 & & & & & & & & & \\
\hline LOV & $0.70 * *$ & 1.00 & & & & & & & & \\
\hline LUA & -0.16 & -0.17 & 1.00 & & & & & & & \\
\hline LLA & -0.17 & $-0.50 *$ & $0.49^{*}$ & 1.00 & & & & & & \\
\hline LUF & 0.37 & $0.56^{*}$ & 0.25 & -0.24 & 1.00 & & & & & \\
\hline LLF & 0.19 & $0.48^{*}$ & 0.41 & -0.30 & $0.78 * *$ & 1.00 & & & & \\
\hline LOS & 0.34 & 0.26 & -0.16 & $-0.49 *$ & 0.26 & 0.23 & 1.00 & & & \\
\hline LOC & $0.43^{*}$ & 0.20 & -0.37 & $-0.45^{*}$ & 0.04 & -0.14 & $0.77 * *$ & 1.00 & & \\
\hline BOC & 0.28 & 0.02 & $-0.42 *$ & -0.40 & -0.34 & -0.07 & 0.40 & $0.48^{*}$ & 1.00 & \\
\hline NSC & -0.33 & -0.19 & $-0.47 *$ & -0.24 & $-0.45^{*}$ & -0.33 & -0.17 & -0.07 & 0.17 & 1.00 \\
\hline
\end{tabular}

$* P<0.05 ; * * P<0.01$

"LOF = Length of flower, LOV = Length of ovary, LUA = Length of two upper anthers, LLA = Length of two lower anthers, LUF $=$ Length of two upper filaments, LLF $=$ Length of two lower filaments, LOS = Length of stigma, LOC $=$ Length of capsule, $\mathrm{BOC}=$ Breadth of capsule, $\mathrm{NSC}=$ Number of seeds per capsule. 
Table 4: Eigenvectors and percentage explained variation by the first three principal components of the sesame floral characters

\begin{tabular}{l|lll}
\hline \multirow{2}{*}{\multicolumn{1}{c|}{ Characters }} & \multicolumn{3}{|c}{ Eigenvectors } \\
\cline { 2 - 4 } & PC1 & PC2 & PC3 \\
\hline Length of flower & 0.71 & 0.08 & 0.21 \\
Length of ovary & 0.75 & 0.25 & -0.32 \\
Length of two upper anther & -0.27 & 0.75 & 0.32 \\
Length of two lower anther & -0.69 & 0.32 & 0.47 \\
Length of two upper filament & 0.56 & 0.70 & -0.18 \\
Length of two lower filament & 0.48 & 0.66 & -0.27 \\
Length of style & 0.74 & -0.20 & 0.33 \\
Length of capsule & 0.66 & -0.46 & 0.42 \\
Breadth of capsule & 0.39 & -0.63 & 0.17 \\
Number of seeds per capsule & -0.25 & -0.61 & -0.59 \\
Eigenvalue & 3.41 & 2.74 & 1.26 \\
Individual percentage & 34.13 & 27.46 & 12.62 \\
Cumulative percentage & 34.13 & 61.59 & 74.22 \\
\hline
\end{tabular}

Seventeen accessions/landraces of sesame were broadly divided into two groups (Group A and B) using hierarchical clustering technique (Table 5). Group A had only one cluster (cluster I) containing five members with plants in this group recording the highest mean value for number of seeds per capsule (57.67) (Table 6). There were three clusters in Group B (cluster II, III, IV). In cluster II were seven accessions/landraces with plants recording highest mean value for length of the two lower anthers (0.40). Cluster III had three landraces from Jigawa and Katsina States. These three landraces are white seeded with the highest mean values for length (2.87) and breadth of capsules (0.86). Cluster IV had only two members with plants manifesting the highest mean values for most of the reproductive characters (length of flower, length of ovary, length of two upper anthers, length of two upper and lower filaments, and length of style). Dendrogram of relationship among the accessions and landraces (Fig. 1) revealed results that were consistent with the results of hierarchical clustering in Table 5. The same clustering pattern was observed in which all the accessions and landraces were recognized in the dendrogram with Euclidean dissimilarity coefficient mean of 12.5 delineating the main phenotypically related groups.

\section{DISCUSSION}

Medium variability were observed for floral characters such as length of ovary, length of flower, length of capsule and length of style of the accessions studied. This is promising from the view point of genetic improvement of flower size in sesame, which may subsequently translate into big capsule size and probably high seed yield. The importance of a trait is given by its discriminating power in the accessions and its stability of expression (Arriel et al., 2007). Floral characters are known to be expressively stable and in most cases less affected by the environment as suggested by their narrow to medium variability. An analysis of association between various plant characters helps in identifying the most important characters (Sarwar et al., 2005; Azeez and Morakinyo, 2011c). The strong positive correlations of length of ovary versus length of flower and length of capsule versus length of style can be exploited directly in the selection for long capsule with a view to increase the number of seed per capsule and subsequently bringing about improvement in sesame seed yield.

In this study, principal components analysis revealed that all characters took effect in the first two components. Characters that had higher values in the first ended up having lower values in the second and those characters that had lower values in the first ended up having higher values in the 
second suggesting that all the characters considered are important in determining genetic variation. Length of flower, length of ovary, length of style and length of capsule were loaded with positive signs $(0.71,0.75,0.74$ and 0.66 respectively) and also exhibited high correlations. Traits with positive loading and high correlation might be influenced by the same gene or set of genes (Biabani and Pakniyat, 2008). Thus, selection based on these floral characters may be more efficient in screening for capsule size in sesame. This study has also shown the consistency between the dendrogram and the cluster grouping of the accessions, indicating that either of the tools is sufficient to illustrate diversity among the accession/landraces.

Table 5: Cluster composition of seventeen sesame accessions and landraces evaluated

\begin{tabular}{llll}
\hline Group & Cluster & Number of accessions & Accession code (No) \\
\hline A & $\mathrm{I}$ & 5 & C-K2-1, BATSARI L, IBS, ALO, E-8 \\
\cline { 2 - 5 } & $\mathrm{II}\left(\mathrm{b}_{1}\right)$ & 7 & $\begin{array}{l}\text { 69B-882, EVA, PACH, GUMEL L, C-K2-2, S530, } \\
\text { ZABURAN L }\end{array}$ \\
\cline { 2 - 5 } $\mathrm{B}$ & $\mathrm{III}\left(\mathrm{b}_{2.1}\right)$ & 3 & DAN, DANEKA I, DANKASCO L, DANKASCO I \\
\cline { 2 - 5 } & $\mathrm{IV}\left(\mathrm{b}_{2.2}\right)$ & 2 & AYK, 65-8B \\
\hline
\end{tabular}

Table 6: Cluster composition of seventeen sesame accessions and landraces

\begin{tabular}{lllll}
\hline \multirow{2}{*}{ Characters } & \multicolumn{3}{c}{ Clusters } \\
\cline { 2 - 5 } & I & II & III & IV \\
\hline Length of flower & 2.82 & 2.59 & 3.17 & 3.19 \\
Length of ovary & 0.36 & 0.30 & 0.40 & 0.45 \\
Length of two upper anthers & 0.33 & 0.37 & 0.33 & 0.38 \\
Length of two lower anthers & 0.25 & 0.40 & 0.33 & 0.30 \\
Length of two upper filaments & 1.04 & 1.00 & 1.00 & 1.17 \\
Length of two lower filaments & 0.94 & 0.90 & 0.90 & 0.99 \\
Length of style & 1.22 & 1.10 & 1.20 & 1.27 \\
Length of capsule & 2.77 & 2.33 & 2.87 & 2.53 \\
Breadth of capsule & 0.86 & 0.82 & 0.86 & 0.80 \\
Number of seeds per capsule & 57.67 & 52.33 & 44.33 & 38.67 \\
\hline
\end{tabular}




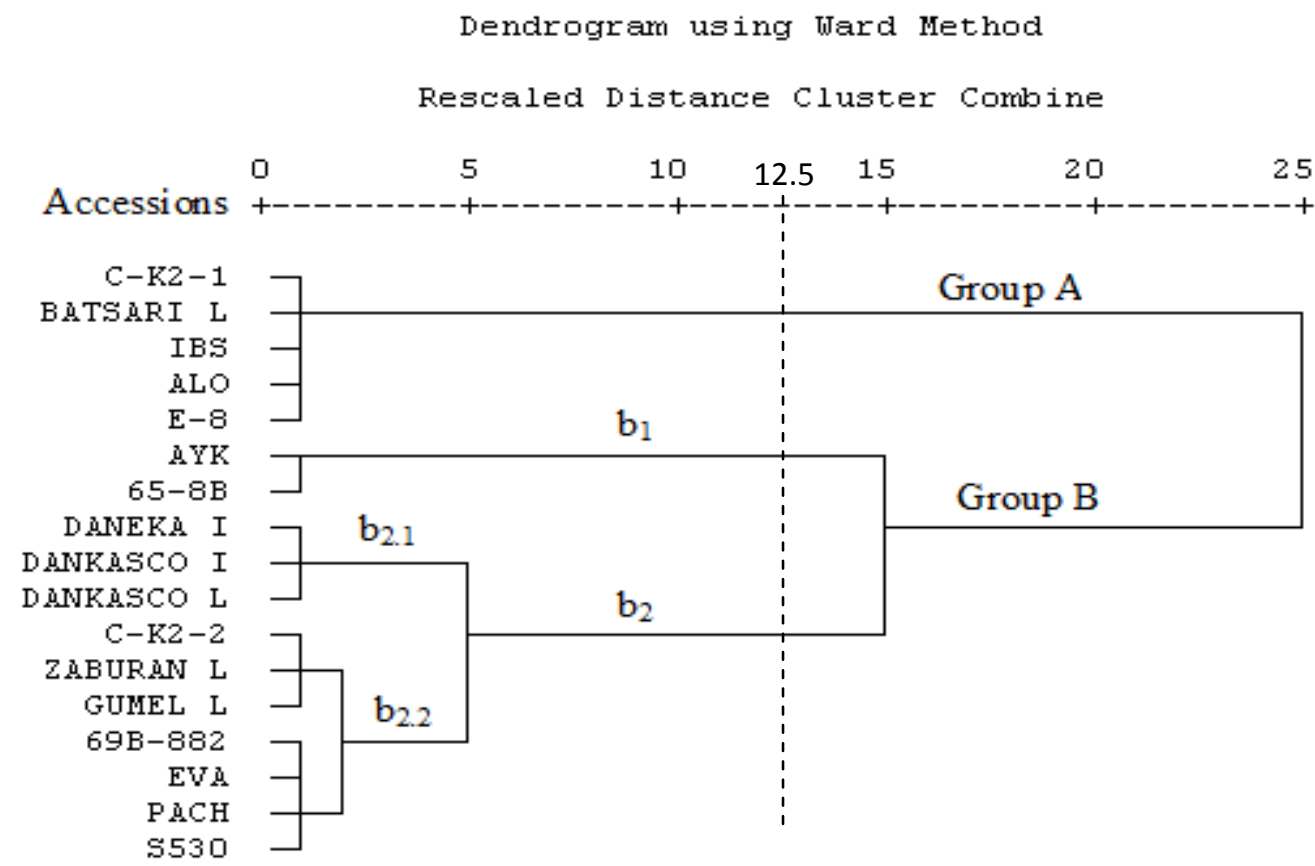

Figure 1: Dendrogram of seventeen accessions and landraces of sesame included in the study

The accessions were initially grouped into two groups consisting of four clusters. Accessions in cluster I showed variety of seed colors from white through light brown to black, while those in cluster II were all white seeded except 69B-882 with brown color. Accessions in cluster III were also white seeded whereas those in cluster IV consist of black (AYK) and brown (65-8B) seeded types. Clustering of accessions/landraces from different eco-geographical locations into one cluster were observed in this study which are attributable to the possibility of free exchange of breeding materials among widely separated locations (Banerjee and Kole, 2009). Some accessions/landraces of common geographical locations (Batsari L and Daneka I) were also observed to form different clusters, a situation that may be explained by their parental developmental traits, past history of selection and different outcrossing rates (Bhat et al., 1999). Accessions within each cluster seem to be more related genetically than members of other clusters based on one or two characteristics, indicating that members in the same cluster may represent one heterotic group. The use of accessions across distinct heterotic group as parents in crossbreeding results in the achievement of maximum variability for selection in the segregating population (Genet et al., 2005).
Comparatively, previous studies have shown that multivariate analyses of protein variation (Azeez et al., 2013), seed physical dimension (Azeez and Morakinyo, 2011a), and seed oil and fatty acid profile (Azeez and Morakinyo, 2011b) recorded $45.70 \%, 88.96 \%$ and $80.95 \%$ for the first two principal components respectively. In some other investigations on sesame, multivariate analysis of morpho-physiological (Tabatabaei et al., 2011) and morpho-agronomic (Ercan et al., 2002) traits yielded $38.51 \%$ and $45.30 \%$ respectively for the first two principal components, while that of phytochemical characters recorded $91.86 \%$. (Laurentin et al., 2003). However, in the present study on floral characters, the first two principal components recorded $61.59 \%$ suggesting medium variability for floral characters. Generally, biochemical (physio-chemical and fatty acid profile) characters and seed physical dimensions appear to be the most effective in distinguishing among the accessions/landraces, followed by the floral characters while protein, morpho-agronomic and physiological traits are probably the least effective. Nevertheless, the results of this investigation have underscored the usefulness of floral characters in delimiting taxa and subsequently distinguishing among the accessions/landraces of sesame. 


\section{CONCLUSION}

Floral characters employed in this study have shown medium genetic variability. Correlation study revealed strong positive association for length of ovary versus length of flower and length of capsule versus length of style. The seventeen accessions and landraces of sesame evaluated using quantitative floral characters were divided into four clusters representing different heterotic groups. Multivariate analysis in this study has provided tools for bringing accessions that are genetically similar together and separating them from other members hence depicting genetic variation. This finding will enhance selection of good parent plant based on floral characters towards improvement of sesame yield in Nigeria.

\section{ACKNOWLEDGEMENT}

Authors are thankful to the authorities of LAUTECH for providing materials and support for this work.
Conflict of interest: Authors declare no conflict of interest.

\section{REFERENCES}

Adéoti K., Rival A., Dansi A., Santoni S., Brown S., Beule T., Nato A., Henry Y., Vodohue R., Loko L. Y., Sanni A. 2011. Genetic characterization of two traditional leafy vegetables (Sesamum radiatum Thonn, ex Hornem and Ceratotheca sesamoides Endl.) of Benin, using flow cytometry and amplified fragment length polymorphism (AFLP) markers. African Journal of Biotechnology, 10: 14264-14275. doi:10.5897/AJB11.1176

Akbar F., Rabbani M. A., Masood M. S., Shinwari Z. K. 2011. Genetic diversity of sesame (Sesamum indicum L.) germplasm from Pakistan using RAPD markers. Pakistan Journal of Botany, 43: 21532160

Alege G. O. 2015. Protein profile study of some Nigerian sesame (Sesamum indicum L.) accessions. International Journal of Applied Sciences and Biotechnology, 3: 322-329. doi:10.3126/ijasbt.v3i2.12734

Anon. 2002. Overview of the Nigerian Sesame Industry. Chemonic International Incorporation, Washington DC, 20036: 34p

Arriel N. H. C., Mauro A. O. D., Arriel E. F., UnêdaTrevisoli S. H., Costa M. M., Bárbaro I. M., Muniz F. R. S. 2007. Genetic divergence in sesame based on morphological and agronomic traits. Crop Breeding and Applied Biotechnology, 7: 253-261. doi:10.12702/1984-7033.v07n03a04

Ashri A. 1989. Sesame. In: G. Roebblen, R. K. Downey \& A. Ashri (Eds), Oil crops of the world, McGraw Hills Publishing Co., New York, 13p
Azeez M. A., Morakinyo J. A. 2011a. Genetic diversity of the seed physical dimensions in cultivated and wild relatives of sesame (Genera Sesamum and Ceratotheca). International Journal of Plant breeding and Genetics, 5: 369 - 378. doi:10.3923/ijpbg.2011.369.378

Azeez M. A., Morakinyo J. A. 2011b. Genetic diversity of fatty acids in sesame and its relatives in Nigeria. European Journal of Lipid Science and Technology, 113: 238-244. doi:10.1002/ejlt.201000080

Azeez M. A., Morakinyo J. A. 2011c. Path analysis of the relationships between single plant seed yield and some morphological traits in sesame (Genera Sesamum and Ceratotheca). International Journal of Plant breeding and Genetics, 5: 358 - 368 . doi:10.3923/ijpbg.2011.358.368

Azeez M. A., Aremu C. O., Olaniyan O. O. 2013. Assessment of genetic variation in accessions of sesame (Sesamum indicum L.) and its crosses by seed protein electrophoresis. Journal of Agroalimentary Processes and Technologies, 19: 383-391.

Banerjee P.P., Kole P.C., 2009. Analysis of genotypic diversity in sesame (Sesamum indicum L.) based on some physiological characters. Czechoslovakia Journal of Genetics and Plant Breeding, 45: 72-78.

Bedigian D. (2003). Evolution of sesame revisited: domestication, diversity and prospects. Genetic Resources and Crop Evolution, 50: 779 - 787. doi:10.1023/A:1025029903549 
Bedigian D. 2006. Assessment of sesame and its wild relatives in Africa. In Ghazanfar, S. A. and H. J. Beentje, editors. eds. Taxonomy and Ecology of African Plants, Conservation and Sustainable Use Royal Botanic Gardens. Kew: 11p.

Bhat K. V., Babrekar P. P., Lakhanpaul S. 1999. Study of genetic diversity in Indian and exotic sesame (Sesamum indicum L.) germplasm using random amplified polymorphic DNA (RAPD) markers. Euphytica, $\quad 110$ : $\quad 21 \quad$ - $\quad 33$. doi:10.1023/A:1003724732323

Biabani A. R., Pakniyat H. 2008. Evaluation of seed yield-related characters in sesame (Sesamum indicum L.) using factor and path analysis. Pakistan Journal of Biological Sciences, 11: 1157-1160. doi:10.3923/pjbs.2008.1157.1160

Buzgo M., Soltis D. E., Soltis P. S., Ma H. 2004. Towards a comprehensive integration of morphological and genetic studies of floral development. Trends in Plant Science, 9: 164-173. doi:10.1016/j.tplants. 2004.02.003

Ercan A. G., Taşkin K. M., Turgut K., Bilgen M., Firat M. Z. 2002. Characterization of Turkish sesame (Sesamum indicum L.) landraces using agronomic and morphologic descriptors. Journal Faculty of Agriculture Akdeniz University, 15: 45-52,

Falusi O. A., Salako E. A. 2001. Assemblage of sesame germplasm for conservation and genetic improvement in Nigeria. PGR Newsletter, 127: 35 -38 .

Furini A., Wunder J. 2004. Analysis of eggplant (Solanum melongena)-related germplasm: morphological and AFLP data contribute to phylogenetic interpretations and germplasm utilization. Theoretical and Applied Genetics, 108: 197-208. doi:10.1007/s00122-003-1437-1

Genet T., Labuschagne M. T., Hugo A. 2005. Genetic relationships among Ethiopian mustard genotypes based on oil content and fatty acid composition. African Journal of Biotechnology, 4: 1256-1268.

Hiremath S. C., Patil C. G. (1999). Genome homology and the putative progenitor of sesame. Journal of Cytology and Genetics, 34: 69 - 74

Isshiki S., Umezaki T. 1997. Genetic variation of isozymes in cultivated sesame (Sesamum indicum L.). $\quad$ Euphitica, 375-377. doi:10.1023/A:1002985625087

Kobayashi T. 1981. The type classification of cultivated sesame based on genetic characters. In: A. Ashri (ed.), Sesame: status and improvement. FAO Plant Production and Protection Paper 29, Rome: 4p.
Kumar A. K. M. S., Hiremath S. C. 2008. Cytological analysis of interspecific hybrid between Sesamum indicum $\mathrm{L} \times \mathrm{S}$. Orientale L. Var. malabaricum. Karnataka Journal Agriculture Science, 21: 498502 .

Langham D. R. 2007. Phenology of Sesame. In: Janick, J. and Whipley, A. eds.: Issues in New Crops and New Uses., ASHS Press, Alexandria, VA: 39p

Laurentin H., Pereira C., Sanabria M. 2003. Phytochemical characterization of six sesame ( Sesamum indicum L.) genotypes and their relationships with resistance against the sweetpotato Whitefly Bemisia tabaci Gennadius. Agronomy Journal, 95 . doi:10.2134/agronj2003.1577

Mohamed H. M. A., Awatif I. I. 1998. The use of sesame oil unsaponifiable matter as a natural antioxidant. Food Chemistry, 62: 269-276. doi:10.1016/S0308-8146(97)00193-3

Nanthakumar G., Singh K. N., Vaidyanathan P. 2000. Relationships between cultivated sesame (Sesamum sp.) and the wild relatives based on morphological characters, isozymes and RAPD markers. Journal of Genetics and Breeding, 54: 5 - 12

Nyongesa B. O., Were B. A., Gudu S., Dangasuk O. G., Onkware A. O. 2014. Genetic relationship between sesame (Sesamum indicum L.) and related wild species based on chromosome count and isozyme markers. African Journal of Agricultural Research, 9: 1052-1060. doi:10.5897/AJAR2013.8500

Pathak N., Rai A. K., Kumari R., Thapa A., Bhat K. V. 2014. Sesame crop: an underexploited oilseed holds tremendous potential for enhanced food value. Agricultural Sciences, 5: 519-529. doi:10.4236/as.2014.56054

Ruhi M. K., Majd A., Jonoubi P. 2015. Study of anatomical structure of vegetative organs, floral meristem and pollen development in sesame. International Journal of Plant Animal and Environmental Sciences, 5: 232-240

Sarwar G., Haq M. A., SaleemMughal M. 2005. Genetic parameters and correlation study in diverse types of sesame germplasm. Sesame and Safflower Newsletter, 20: $34-39$

Suarez-Cervera M., Eoane-Camba J., Lobreau-Callen D. 1992. Pollen morphology and pollen-wall proteins (localization and enzymatic activity) in Sesamothamnuslugardii (Pedaliaceae). Plant Systematics Evolution, 183: 67-81. doi:10.1007/BF00937736

Tabatabaei I., Pazouki L., Bihamta M. R., Mansoori S., Javaran M. J., Niinemets Ü. 2011. Genetic variation 
among Iranian sesame (Sesamum indicum L.) accessions vis-à-vis exotic genotypes on the basis of morpho-physiological traits and RAPD markers. Australian Journal of Crop Science, 5: 1396-1407

Uzo J. O., Adedzwa D. K., Onwukwe R. O. 1985. Yield, yield components and nutritional attributes of cultivated sesame $\mathrm{S}$. indicum and its endemic wild relatives in Nigeria. In: A. Ashri (ed.), Sesame and safflower: status and potential. FAO Plant production and Protection Paper 66, Rome: 11p
Wei W., Qi X., Wang L., Zhang Y., Hua W., Li D., Lv H., Zhang X. 2011. Characterization of sesame (Sesamum indicum L) global transcriptome using illumine paired-end sequencing and development of EST-SSR markers. BMC Genome, 12: 451. doi:10.1007/BF00937736

Zhigila D. A., Sawa F. B. J., Abdul S. D. 2015. Morphometric study of accessions of Sesamum indicum L. collected from Nigeria. African Journal of Plant Sciences, 9: 56-64. doi:10.5897/AJPS2014.1180 